JOGOS INDÍGENAS

\section{Etnias brasileiras jogavam bola antes da chegada de Charles Miller}

As atividades esportivas praticadas pelos povos indígenas sul-americanos é bem antiga. Pode-se afirmar que praticavam vários jogos antes da chegada dos colonizadores. Até os dias atuais, são várias as manifestações esportivas que fazem parte dos rituais desses povos, com destaque para aqueles realizados com bola, sendo o mais representativo o de bola com a cabeça, também conhecido como cabeçabol.

Essejogo, chamadoxikunahity (pronuncia-se zikunariti) na língua dos Paresi e hiara na língua dos Enawenê Nawê é parecido com o futebol mas, em lugar de chutar, as equipes devem cabecear a bola. Segundo as tradições indígenas, crianças e mulheres ficam de fora e o jogo é disputado em ocasiōes especiais apenas pelos homens, com grande tradição nos povos Paresi, Salumã, Irántxe, Mamaidê e Enawenê-Nawê, todos do Mato Grosso.

Dentre os participantes estão duas equipes com no mínimo oito atletas. A partida se realiza em um campo de terra batida para que a bola ganhe impulso. O campo tem tamanho semelhante a um campo de futebol e conta somente com uma linha demarcatória no centro que delimita o espaço de cada equipe.

A partida começa com atletas veteranos, um de cada equipe, que se diri-

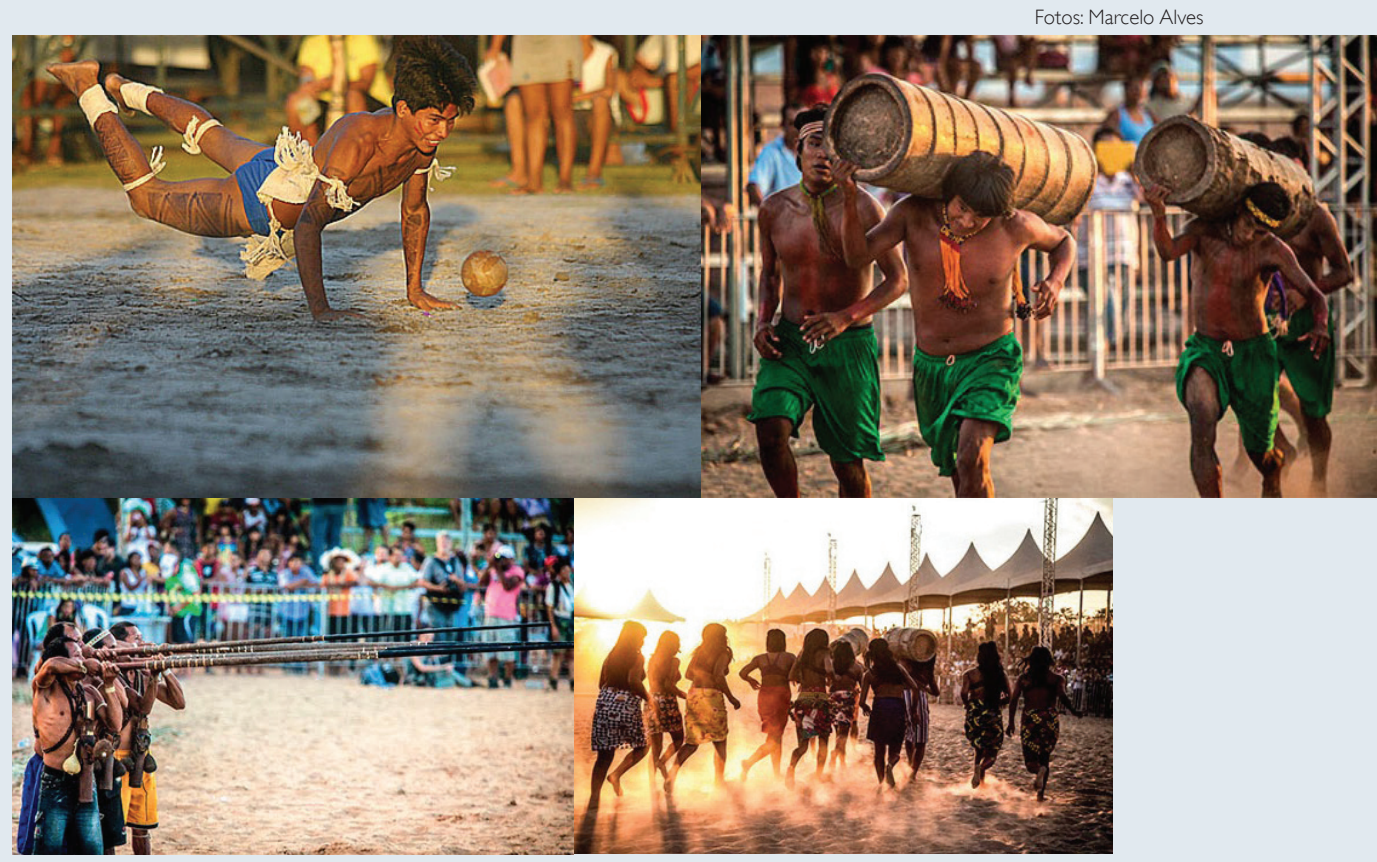

Atleta praticam xikunahity durante Olimpíadas Indígenas

gem ao centro do campo para decidir quem irá lançar a bola. $\mathrm{O}$ jogo continua com a primeira cabeçada para o campo adversário que deverá ser recepcionada também com a cabeça. Em seguida os atletas veteranos deixam imediatamente o campo, pois a responsabilidade deles é somente fazer o lançamento inicial da partida durante a qual a bola não pode ser tocada com as mãos, pés ou qualquer outra parte do corpo, podendo apenas ser tocada com a cabeça e também no solo antes de ser rebatida por outro jogador. A equipe marca pontos quando a bola não é devolvida pelos adversários, não existem as traves de gols. Como em outras modalidades, quanto maiores são as habilidades dos atletas mais emocionantes são as partidas, que podem durar mais de quarenta minutos.

Uma lenda Paresi conta que o xikunahity foi criado pela principal entidade mítica da cultura deles, o
Wazare, que, depois de cumprir sua missão de distribuir o povo Paresi por toda uma região, fez uma grande festa de confraternização antes de voltar ao seu mundo.

Com aproximadamente $30 \mathrm{~cm}$ de diâmetro, a bola é feita pelos índios a partir de um tipo de látex obtido da seiva da mangabeira, árvore típica do cerrado brasileiro.

Em comemoração à Semana do Índio, em abril deste ano, foi possível apreciar essa e outras atividades esportivas durante o Festival Nacional da Cultura Indígena, em Bertioga (SP). Em julho de 2015, o Brasil hospedará os Jogos Mundiais dos Povos Indígenas e receberá etnias de várias partes do mundo, em uma verdadeira festa, com muitos rituais nos quais as identidades culturais de cada etnia estarão representadas.

Vera Toledo de Camargo 